\title{
Inheritance of Aesthetic Education in Universities
}

\author{
Chenghui Yang ${ }^{1}$, Yubin Wang ${ }^{1}$, Ning Cai ${ }^{1}$, Hongjie $\mathrm{Bao}^{2}$ \\ 1College of Electrical Engineering, Northwest Minzu University \\ 2 College of Management, Northwest Minzu University \\ Lanzhou, China \\ yangchenghui36@163.com
}

\begin{abstract}
In order to strengthen the core socialist values and aesthetic education in colleges and universities. Through the method that a consciousness and the coordination of the three links, two positions to support each other to promote the aesthetic education in Colleges and universities. The teachers' cultural literacy and the construction of curriculum system should be valued in classroom. The management staff of aesthetic education should be concerned in extracurricular activities of aesthetic education. So as it can play a positive role in aesthetic education. Therefore, it can be seen that the development of aesthetic education has become an important task of Ideological and political education in colleges and universities.
\end{abstract}

Keywords-Aesthetic culture colleges; universities Ideological; political education

\section{THE IMPORTANCE OF AESTHETIC EDUCATION CULTURE}

\section{A. Thinking from the perspective of cultural inheritance}

Chinese excellent traditional culture as the "foundation" of core socialist values which has a long history of five thousand years and broad and profound culture. The first should be included of it is thought, character, language and the classical six arts. After that, it is the calligraphy, music, martial arts, folk art, chess, festival, folk custom and so on. Therefore it becomes an important source of core socialist values. Cultivate and practice the socialist core values which must be based on the Chinese excellent traditional culture. Aesthetic education in Colleges and universities is an important form of inheriting and innovating Chinese excellent traditional culture, and it also as an important form of inheritance and innovation of Chinese traditional culture, has many bonding points. Therefore, we can carry out many practical activity of excellent Chinese traditional culture about aesthetic education to highlight the beauty of traditional culture [2].

\section{B. Thinking from the perspective of innovation and \\ development}

The general secretary Jingping $\mathrm{Xi}$ pointed out that it is necessary to carry out the core socialist values in all aspects of social life. Therefore, through a series of practical and reliable way to make the core socialist values into people's spiritual pursuit, to make it becomes conscious action. This is a kind of life, this is also the sum of spiritual life and material life.
Cultivating and carrying forward the core socialist values is the basis of realizing the beautiful Chinese dream and the objective need of the great rejuvenation of the Chinese nation. From this point, aesthetic education in Colleges and universities is an important carrier to strengthen the education of core socialist values. We can set up and develop new research topics, carry out related research activities to highlight the beauty of life happiness. At the same time, in the study of theoretical knowledge, we can cultivate and improve students' aesthetic and cultural qualities.

\section{Thinking from the perspective of aesthetic research}

"Prosperity, democracy, civilization and harmony" reflects the beauty of the three aspects of the Chinese nation's happy life that is the beauty of "national vision"; "Freedom, equality, justice and rule of law" is the beauty of "social environment"; stable social, freedom and equality for all people is the external guarantee of people's happiness. "Patriotism, dedication, integrity, friendliness" is the beauty of "citizen quality". Everyone has a noble morality and graceful personality is the inner expression of people's happiness. The beauty of "national vision", "social environment" and "citizen quality" are the three levels of "beauty" which are the symbol and connotation of people's happiness. That is to say that people live in the beauty of "national vision", "social environment" and "citizen quality". This is a beautiful, wonderful and happy life. Therefore, higher education is the two aspects of quality education in Colleges and universities, which are not only independent but also closely linked. It is also an effective way to complete the task of training high-quality personnel in Colleges and universities. The core socialistic value system which can determine the direction of the development of socialism with Chinese characteristics is the soul of rejuvenating the country.

\section{Thinking from the perspective of educational essence}

It is harmonious for aesthetic education to be gave cultural connotation and the concept of cultural quality education and this is the essential choice of Education. At the same time, with the continuous improvement of the quality of College Students The cultural pursuit of the students' aesthetic education curriculum is also increasing. The students hope that through the study of art elective courses, we can get the ability to know beauty, love beauty and create beauty. The students also hope that through the course of learning to understand the different 
types of art behind the representative of the regional culture and historical origin. Art education is no longer the teaching of technical skills, but also the dissemination of art and culture, human outstanding culture [6].

\section{THE THOUGHT OF AESTHETIC EDUCATION IN COLLEGES AND}

\section{UNIVERSITIES}

On the file of "Opinions on strengthening and improving the work of aesthetic education in schools", in the current and future period of time, the general office of the State Council pointed out the guiding ideology, basic principles, general goals and policy measures for strengthening and improving the work of aesthetic education. Make an important explanation for the modern aesthetic education system with Chinese characteristics. Aesthetic education is the education of the mind and it is an important way to improve the basic quality of a person, a school and a society. The CPC and the State Department attach great importance to school aesthetic education since it is an important carrier to strengthen the education of core socialist values, as an important form of inheritance and innovation of Chinese traditional culture, as an important aspect of the fundamental task of implementing moral education, as an important part of deepening the comprehensive reform in the field of Education [3].

Among them, the idea of aesthetic education in college has the following significance:

- Aesthetic education has a positive influence on moral education, intellectual education and physical education

- The aesthetic education with the beautiful and touching artistic image can help college students to understand people's life, ideal and struggle. To enable them to receive the ideological and moral education, promote the healthy growth of their political quality, moral outlook and thoughts and feelings [8].

- Aesthetic education can not only help the students to understand reality and history, but also develop their ability of observation, imagination, image thinking and creativity [7].

\section{THE MAIN RESEARCH CONTENTS OF AESTHETIC}

\section{EDUCATION}

\section{A. Research goals}

Aesthetic education is not only the basis for the implementation of quality education but also the carrier of Aesthetic Psychology of Chinese traditional culture and it is an effective way to realize cultural consciousness. Aesthetic education plays an important role in shaping College Students' healthy personality, cultivating and practicing core socialist values. There are rich aesthetic elements in the course of engineering Specialty. The curriculum and teaching targets should be arranged reasonably in the implementation of aesthetic education. We should develop and integrate the related courses of Engineering Specialty in Colleges and universities, so as to realize the educational aim of aesthetic education [4].

\section{B. Main studying contents}

The two most important positions of aesthetic education in Colleges and universities are classroom teaching and extracurricular art activities. This is also the important point of aesthetic education. There are two key points in the classroom teaching that is teachers' cultural literacy and the construction of curriculum system. The point of extracurricular activities of aesthetic education is the cultural quality of the management of aesthetic education and aesthetic education. It includes the choice of the theme of aesthetic education, the choice of the external manifestation of aesthetic education.

\section{Aesthetic teacher and Aesthetic Curriculum}

Teachers of aesthetic education are the engineers of human soul and the mentors for the growth of young students. Their ideological and political quality, moral sentiment which has a strong influence and appeal to young students, plays a very important role in the dissemination of ideas. This requires the university teachers with a high sense of social responsibility to teach students, be a model for others, In order to make college students have a silent transforming influence in the ideological and moral quality. Practical considerations for the future development of Subject technology, high quality engineering teachers of Colleges and Universities generally focus on the top comprehensive universities and professional art colleges. The regular universities and local colleges even the universities of Science and Technology and comprehensive universities which with a good rank are difficult to attract the high-quality teachers. In this case, a small number of outstanding teachers who has a sense of cultural awareness, attention to politics can apply the advanced teaching idea of "knowledge, culture and current affairs" to the practical teaching work. However, some teachers lack the correct and reasonable teaching ideas, so professional knowledge and skills can't be integrated with the culture, do not understand the current political information, it is not to mention the effective integration of knowledge, culture and politics. Such teachers also exist universally in teacher's group of aesthetic education .Therefore, not only to enhance their own aesthetic education, that is, aesthetic education teachers, but also in the engineering curriculum and aesthetic education to find a good point, that is, the construction of the aesthetic education curriculum.

\section{Management workers of aesthetic education and the activities of aesthetic education}

The management staff of aesthetic education is the leader and planner of the aesthetic education in Colleges and universities who communicate the national policy to everyone. The aesthetic education concept of aesthetic education management workers plays an important role in the implementation of aesthetic education in Colleges and universities. The activity of aesthetic education is an important form to spread aesthetic education. Through these activities, students and teachers can know more about the aesthetic education culture and learn aesthetic education culture. 


\section{E. Key points and difficulties}

The problem of food safety, the problem that most people don't be willing to help the elderly, the conflicts between doctors and patients and so on, can't be ignored in today's China. The root cause is the lack of "morality" in the whole society. The acquisition of morality depends not only on moral knowledge, but also on moral practice. The practice of morality requires the whole society to have higher cultural quality and spiritual pursuit. However, the auxiliary function of aesthetic education is not only the requirement of aesthetic education characteristics. It can also give people the feeling of truth, goodness and beauty, which is the true knowledge of self- practice of many people who have accepted the education of aesthetic education. Such as Tsinghua University, teacher Xiaoyun Zheng in summing up the art education at Tsinghua University said that a lot of art students deeply feel the art of learning can enhance the passion of patriotism. Patriotism, love people, attention to society has always been the same.

The cultural soft power is an important factor in the competition of the comprehensive national strength and national interests. We are familiar with the American animation, Hollywood film production, foreign fast food, and foreign festivals. All of this highlight the values of the United States, ideology and other cultural content, a series of cultural phenomena are generally accepted by young people. Young talents are trained through studying in universities. Cultural qualities and cultural spirit of the people have a profound impact on national competition and international identity. Let young people realize that cultural competition has risen to a high degree of national competition and international identity, help to stimulate their cultural crisis and cultural responsibility. Aesthetic education in Colleges and universities, especially in art education, through art elective courses and extra-curricular art practice activities, students can be gave excellent cultural content, stimulate their ability to use local culture to create art.

On the 90 anniversary of Tsinghua University, comrade Jintao $\mathrm{Hu}$ put forward for the first time that the function that the cultural heritage of the university should have is the unshirkable responsibility of College history. In 2012, comrade Jinping $\mathrm{Xi}$ stressed the importance of the cultural and educational positions in the twentieth party conference of University. At the 20 anniversary of the establishment of the National Academy of Sciences, Peking University, Yuan Guiren, Minister of education pointed out that colleges and universities should give full play to the unique advantages of cultural teachers. In the process of creating excellent colleges and universities to promote cultural inheritance and innovation, build a socialist advanced culture, and promote the core socialist values system.

\section{THE PROMOTION OF AESTHETIC EDUCATION IN}

\section{COLLEGES AND UNIVERSITIES}

The work of aesthetic education in Colleges and universities need some specific measures to regulate and guide.it can be summed up as "a consciousness and the coordination of the three links, two positions to support each other".

\section{A. A consciousness and the coordination of the three links}

At present, the general management mechanism of colleges and universities is the school-college-department-discipline group. Each level of aesthetic education and cultural workers should not only understand the construction of the campus culture, but also be familiar with the content of the cultural construction of their duties. The school Party committee should grasp the leadership of the aesthetic education culture of the school. First of all, to reach a consensus in the school leadership, the establishment of aesthetic education is an important part of the construction of campus culture. According to the framework of the middle institutions, combine with the responsibilities of the Department to develop work plans. Then, the Department and the discipline group to come up with some specific measures. A consciousness and the coordination of the three links from the top down can provide a guarantee for carrying out the campus aesthetic education culture [5].

\section{B. Two positions to support each other}

In my opinion, we should focus on methods and investment, pay attention to interaction and build two good positions. To establish the important position of Chinese traditional culture in the course system and improve the proportion of national art courses. Universities with excellent teachers should encourage the innovation of the theory of aesthetic education, promote the innovation of the discipline system and reform the method of scientific research. If lacking of teachers, we can achieve the sharing of high quality teachers.

The teachers of aesthetic education should carry out simultaneously the study of the professional culture and the training of current affairs, renew the teaching idea, and combine the knowledge, culture and current affairs consciously. The conveyance of current politics and literacy training for aesthetic education teachers can be completed with help of the grass-roots Party branch. The workers who manage the aesthetic education should pay attention to the general law of aesthetic education while paying attention to current politics The school can organize some cultural lectures or seminars to provide a platform to help them to communicate with each other. In the final exam, the specific implementation of the aesthetic education should be included in the assessment indications. In the specific teaching, we should pay attention to the culture and the "penetration" of the curriculum.

Colleges and universities should encourage the innovation of campus culture, encourage create artworks that reflects the excellent campus spirit, pay attention to the outstanding contribution of cultural workers. At the same time, in the construction of the art troupe, we must increase the investment of the folk orchestra and opera troupe to ensure the favorable inheritance of traditional culture. In the construction of teachers group of aesthetic education, we must increase the investment of young teachers. The core value of socialism is the core of the socialist core value system, reflecting the fundamental nature and basic characteristics of the socialist core value system. It reflects the rich connotation and practical requirements of the socialist core value system, is the socialist 
core value system of highly condensed and concentrated expression. Since 18th CPC National Congress, the central government attaches great importance to cultivate and practice the core socialist values. The high attention and strong deployment of The Party Central Committee strengthen the socialist core values of education practice which point out the direction of efforts and provide an important follow-up [1]

\section{V.THE INTEGRATION OF AESTHETIC EDUCATION IN COLLEGES AND UNIVERSITIES}

For a long time, due to the influence of the traditional social values of Chinese traditional culture, we overemphasize the social value of moral education. The moral education is regarded as a tool for socialist political service, ignoring the main body of the education. The traditional theory of moral education is based on the concept of possessive existence. Educators tend to educate people in a similar way, which leads to the fact that they are often placed in an objective position in the practice of moral education. This will inevitably lead to the theory and practice of moral education into the "inhuman" embarrassing situation. The main defect of the traditional moral education theory is the neglect of human subjectivity. So the effect of moral education is not ideal.

At present, the way of moral education in our country overemphasizes the education of the system and the inculcation of theory. It pays attention to the moral knowledge, so that the moral education has the characteristics of unity, political and normative. This kind of single conservative theory of indoctrination education, relying on classroom teaching, teachers are often arbitrary to teach students a moral dogma. This way of "theoretical indoctrination" has been unable to meet the development of the Internet era and the growing thirst for new knowledge. This kind of "Theory Inculcation" may cultivate the "good student", but it is difficult to cultivate students' initiative, autonomy and creativity.

The traditional method of moral education is persuasion, example, practical training, guidance, moral evaluation and so on. Educators always tend to set the premise before persuasion. Moreover, in the process of moral education, educators tend to be authoritative. They asked the students to obey, obey the rules and so on. There is no experience of moral feelings and the exercise of morality, not to mention the cultivation of self -judgment, self- selection, self- education and other abilities. Repeated persuasion and education is a metaphor for what Dewey calls a virtue that "Pour it into the psychological and moral caves". It is inevitable cause the serious rebellious psychology for the educational objects.

\section{CONCLUSION}

The purpose of education is to cultivate talents. As an important way to cultivate talents in colleges and universities, aesthetic education can not only cultivate students' sentiment and improve their quality, but also play an important role in setting up students' world outlook, outlook on life and values. The work of aesthetic education in Colleges and universities through the method of "a consciousness and the coordination of the three links, two positions to support each other" to realizes students' moral education. With the help of aesthetic education, we can achieve the goal of all-round development of College students.

\section{ACKNOWLEDGMENT}

This work is supported by Fundamental Research Funds for the Central Universities of Northwest University for Nationalities (Grant 31920160003, Grant 31920170079). And the project also supported by Experiment Funds of Northwest University for Nationalities, Northwest University for Nationalities, China. (Grant NO. SYSKF2017035, Grant NO. SYSKF2017036, Grant NO. SYSKF2017037, Grant NO. SYSKF2017043 , Grant NO. SYSKF2017044). Research Project on Entrepreneurship Education in Gansu Province in 2016: Research on the Innovation and Entrepreneurship Project of "Internet" in MingZu University, Department of Education in Gansu (2016SJCXCYJG-1001.9150) and 2017 Education Reform in College of Electrical Engineering Northwest Minzu University.

\section{REFERENCES}

[1] Jing Xu, "Reflections on carrying out the idea of cultural inheritance in aesthetic education in Colleges and Universities," [J], Journal of China Youth University for Political Sciences, Vol. 3, 2013, pp. 60-63.

[2] Liyuan Zhu, "Aesthetic education and life," [J], Journal of Aesthetic Education, Vol.3, 2015, pp.1-3.

[3] Shuang Qing, "Research on College Students' moral education from the perspective of aesthetic education," [D], 2015.

[4] Ping Yuan, "Aesthetic education and ideological and political education of College Students," [D], 2012.

[5] Xiaomei Zhang, "The dilemma and outlet of Contemporary College Aesthetic Education," [D], (4)2008.

[6] Qi Gong, "The promoting effect of aesthetic education on College Students' Quality Education," [D], 2009.

[7] Xingya Yan, "Reflections on the innovation of aesthetic education in Colleges and Universities," [J], Vol. 2, 2012, pp. 121-122.

[8] Jia Qing, "The characteristics of aesthetic education," [J], Vol. 5, 2009, pp. 29-30. 